\title{
Audit committee structure and bank stability in Vietnam
}

\author{
Quang Khai Nguyen*, Van Cuong Dang \\ University of Economics Ho Chi Minh City
}

\section{ARTICLE INFO}

Article history:

Received 30 September 2019

Revised 26 October 2019 \& 11

December 2019

Accepted 27 December 2019

Published 7 January 2020

\section{Keywords:}

Audit committee structure

Bank stability

External audit

\begin{abstract}
The role of the audit committee in maintaining banking stability is becoming increasingly important. However, there are not many studies have examined the relationship between the audit committee structure and bank stability in developing countries. This paper examines the relation of the audit committee structure and the bank stability in the difference level of bank stability and the role of external audit quality in this relation by employing empirical techniques like 2SLS, S-GMM or quantile regression analysis with panel data, and using a sample of 37 commercial banks in Vietnam from 2002 to 2018. Our empirical results show that bank stability varies negatively with audit committee size, but this relationship is mitigated in banks that use good external audit services. Moreover, we also find that the relation of the audit committee structure and bank stability is heterogeneous, and that it is stronger in banks with higher stability levels. Based on these results, banks that have a large audit committee should consider a high quality external audit service and should increase the proportion of financial and accounting expertise in the audit committee in order to ensure bank stability.
\end{abstract}

\section{Introduction}

Many studies on corporate governance have found that the firms that have a good mechanism to control managers have good performance (Gillan, 2006; John \& Senbet, 1998; Shleifer \& Vishny, 1997). In commercial banks, inefficient governance can lead to more serious failures, because commercial banks are considered special economic organizations due to their unique role as a financial intermediary and a payment system for the economy (Benston, 1965a, 1965b; Cornett, Marcus, Saunders, \& Tehranian, 2006; Fama \& Jensen, 1983). Moreover, banks can also help facilitate better governance for other firms, such as creditors or shareholders (Caprio, Laeven, \& Levine, 2007; Levine \& Barth, 2001).

Some previous studies have focused on ownership structure and bank risk. These studies suggest that all banking activities are governed by shareholders and management decisions. Many studies have found important factors affecting bank risk. For example, Pathan (2009) found a negative correlation between director's independence and risk at US banks. This shows that the quality of management can reduce bank risk. Similarly, Sun and Liu (2014) state that the board of directors' activities are directly supervised by the audit committee. They find banks with long board tenure audit committees have lower total risk and idiosyncratic risk, and banks with busy directors on their audit committees have higher total risk and idiosyncratic risk. In other words, the effectiveness of the audit committee is able to limit risks in banks and financial firms.

Our study contributes to the existing literature in several ways. First, previous studies mostly focus on large banks and financial companies in developed countries - where there is a developed financial market and a good governance environment. Developing countries generally have a lower level of institutional development than industrial countries. Notably, with respect to law and order, contract enforcement, and corruption, Vietnamese banks in our sample lag behind advanced countries. Demirgüç-Kunt and Maksimovic (1998) find that the probability of financial

\footnotetext{
* Corresponding author. 
fragility is positively associated with weaker institutions. Therefore, the role of banks' audit committees in Vietnam may be different to banks in developed countries. Moreover, the agency problem and information asymmetry takes place more in developing countries, and the role of external audits in these countries is particularly necessary. Therefore, the role of an external audit to increase the effectiveness of the audit committee needs to be considered (Fan \& Wong, 2005).

Second, this is the first study to examine the effect of audit committees on bank stability at different levels of stability. Schaeck, Cihak, Maechler, and Stolz (2011) and Schaeck and Cihak (2012) argue that the impact of certain factors, such as size and competition, affect different levels of stability in European banks. Therefore, the risk oversight role of the audit committee in banks that have divergent levels of stability may be very different.

The rest of the paper is structured as follows: We first present a literature review and the hypothesis development; subsequently, we explain the data and research design. We then present the research results and, eventually, our conclusions.

\section{Literature review and hypothesis development}

In this section, we examine the academic literature related to the relationship between audit committee structure and bank stability. Our objective here is to provide an understanding of the research on which the relevant hypotheses are developed. In this regard, this section is structured as two main sections: the relation of audit committee structure and bank stability; and the role of external audit quality in this relation.

\section{Audit committees and bank stability}

Audit committees are an integral part of the required corporate governance system to overview the financial reporting process for Vietnamese listed firms. The first role of the audit committee is important to stakeholders, as better quality financial reporting and disclosure improve market performance (Wild, 1996). The second role of the audit committee has evolved and has progressively been redefined from a voluntary monitoring mechanism employed in high agency cost situations to improve the quality of information flows to shareholders (Pincus, Rusbarsky, \& Wong, 1989). It is now a key component of the oversight function and the focus of increased public and regulatory interest (Abbott, Park, \& Parker, 2000). The implied expectation is that a suitably qualified and committed independent audit committee acts as a reliable guardian of public interest (Abbott, Parker, \& Peters, 2004). For US firms, the audit committee is required to discuss and review the firm's risk assessment and hedging strategies (New York Stock Exchange, 2011). Thus, the audit committee's primary role has evolved to overseeing the financial reporting and risk management processes.

The first purpose of this study is to examine the impact of the audit committee structure on bank stability. Base on agency theory, there is a conflict of interest between managers and shareholders in risk taking. Several studies argue that bank managers may also prefer risky assets (Dewatripont \& Tirole, 1994; Shleifer \& Vishny, 1989). Jensen (1986) also argues that to the extent that wages, promotions and perquisites relate to the firm's growth, managers may invest in risky projects, even those with negative net-present-value (NPV) rather than leave any excess funds un-invested. However, bank shareholders want managers to invest in all positive NPV projects with a reasonable level of risk. Therefore, with the role of overseeing risk management, audit committee structure may affect bank stability. Many previous empirical studies also show that the governance structure has a certain impact on bank efficiency and risk. Pathan (2009) find a negative correlation between board independence and bank risk, as well as a positive correlation between board size and bank risk. Minton, Taillard, and Williamson (2011) found that the proportion of banking and finance professionals in management correlated positively with bank risk. Similarly, Berger, Imbierowicz, and Rauch (2016) show that management age, gender and expertise also affect bank risk. Based on previous studies, Sun and Liu (2014) said that the management of the risk management activities of the board is carried out through the audit committee. Therefore, the structure and operational efficiency of the audit committee directly determines the bank risk, thereby determining bank stability. Recently, Iskandar, Jamil, Yatim, and Sanusi (2018) have found that internal audit work priority contributes significantly to the firm's risk management implementation at all stages. The audit committee has an important role in enhancing the effectiveness of internal audit in the risk management implementation, particularly for the development of policy and procedures and strategy and follow-up actions. Pérez-Cornejo, de Quevedo-Puente, and Delgado-García (2019) have shown that audit committee independence improves corporate reputation through enhancing the quality of the firm's risk management system. They also reveal a positive relationship between the average educational level of independent directors of the audit committee and a firm's risk management system quality. Tai, Lai, and Yang (2018) state that the audit committee plays an important role in the firm's hedging decisions. The characteristics of the audit committee - 
including the number of audit committee members, the number of audit committee meetings, the percentage of financial experts on the audit committee and the number of independent directors - have a significant and positive impact on a firm's decision of whether to hedge.

Since the elements of the audit committee structure may correlate negatively or positively to bank risk, we propose the following hypothesis:

\section{H1: The audit committee structure is correlated with bank stability.}

For extensions, Schaeck and Cihak (2012) studied the relationship between effective competition and bank stability and found that the impact of competition on efficiency varies depending on the level of bank stability. Therefore, the author predicts that the role of the audit committee for bank stability depends on the level of bank stability. Consequently, we hypothesize the following:

\section{H2: There is heterogeneity in the relationship between audit committee structure and bank stability.}

\section{The role of external audit quality}

The agency problems associated with the separation of ownership and control, along with information asymmetry between management and absentee owners, create the demand for the external audit. Fan and Wong (2005) find that in East Asia, firms that are subject to greater agency problems, indicated by their high control concentration, are more likely to hire Big 5 auditors than firms subject to smaller agency problems. This suggests that auditors play a governance role to mitigate agency problems in emerging markets. External auditors are responsible for verifying that the financial statements are fairly stated, in conformity with Lin and Hwang (2010). Moreover, the external auditors are required by auditing standards to discuss and communicate with the audit committee about the quality, not just the acceptability, of accounting principles applied by the client company.

Francis and Schipper (1999) found that Big 5 auditors have to maintain their reputation capital and therefore provide quality-differentiated services. Consequently, a quality audit is expected to support the audit committee to work well on risk management supervision as well as to reduce information risk that the financial reports contain material misstatements or omissions. Furthermore, Hohenfels and Quick (2018) find the audit committees performance are strongly dependent on the external auditor, because the internal audit reports to the CFO and not directly to them. Thus, they cannot directly deploy internal audit resources to support their monitoring function.

Based on the role of external audits recognized in previous studies, this paper hypothesizes the following:

\section{H3: External audit quality is significantly associated with the relationship between audit committee structure and bank stability.}

\section{Data and research design}

This section describes the data and research methodology we employed, and this section is structured into six subsections. Section 3.1 provides details on the sample, data sources, their composition and coverage used in this study. Section 3.2 explains the measurements of bank stability. Sections 3.3, 3.4 and 3.5 explain the measurements of audit committee structure; external audit quality and control variables, respectively. Finally, Section 3.6 provides our empirical model.

\section{Data}

This paper uses the data from Bankscope (Orbis Bank Focus) for the period 2002-2018. The detailed information on bank audit committee structures was hand-collected from bank annual report. After the exclusion of observations with missing data, our dataset consisted of 406 bank year observations for 37 banks.

\section{Measurement of bank stability}

The measurement of bank stability captures the probability of default of a country's banking system. The Z-score is a widely used measure of bank stability (Demirgüç-Kunt \& Huizinga, 2010; Houston, Lin, Lin, \& Ma, 2010; Laeven \& Levine, 2009). It combines banks' buffers (capital and profits) with the risks they face (measured by the standard 
deviation of returns). The $\mathrm{Z}$-score measures the number of standard deviations a return realization has to fall in order to deplete equity.

It is estimated as:

$$
\mathrm{Z}-\text { score }=\frac{\mathrm{ROA}+\mathrm{E} / \mathrm{A}}{\mathrm{Sd}(\mathrm{ROA})}
$$

ROA is the return on assets, and $\mathrm{SD}(\mathrm{ROA})$ is the standard deviation of ROA. E/A is the equity on assets ratio. Thus, the Z-score is the number of standard deviations by which a bank's return on assets has to fall for the bank to become insolvent. A higher Z-score implies a lower probability of insolvency and higher stability, providing a direct measure of stability that is superior for analyzing leverage.

We also use the aggregate ratio of nonperforming loans to total loans as a dependent variable. The non-performing loans ratio is another regularly used measure of stability (Dwumfour, 2017; Jimenez, Salas, \& Saurina, 2006). This measures the lending risk of the banking system. The loan amount recorded as non-performing includes the gross value of the loan as recorded on the balance sheet, not just the amount that is overdue. The lesser the ratio, the better it is for stability.

\section{Measurement of audit committee structure}

Based on the literature on boards of directors and their committees, we consider the following four audit committee characteristics that proxy audit committee structure.

(1) Accounting or financial expertise.

Xie, Davidson III, and DaDalt (2003) and Bédard, Chtourou, and Courteau (2004) find that firms with accounting experts on the audit committee have a negative relation to earnings management. G. V. Krishnan and Visvanathan (2008) find a positive association between accounting conservatism and audit committees' accounting or financial expertise. Dhaliwal, Naiker, and Navissi (2010) find that firms have higher accruals quality when their audit committees have at least one accounting or financial expert. Krishnan and Visvanathan (2008) also document a positive association between accounting conservatism and audit committees' accounting or financial expertise. Dhaliwal et al. (2010) find that firms have higher accruals quality when their audit committees have at least one accounting or financial expert. These studies suggest that accounting or financial expertise plays an important role in the oversight of managers. Tai et al. (2018) find that the higher proportion of financial experts the in audit committee, the higher the incentive to hedge and the higher the likelihood to have a higher hedge ratio or get lower risk. However, Sun and Liu (2014) find no evidence about the relationship between financial expertise and banks' risk-taking behaviors. Following Pathan (2009), we define audit committee members with accounting or financial expertise as a person who has experience as an accountant or auditor, or experience in the financial sector (including possessing an accounting or finance degree). Our first measure of audit committee structure is the proportion of directors with accounting or financial expertise on the audit committee.

(2) Audit committee independence

The Institute of Internal Auditors state that: "An independent audit committee member is a person who is not employed by, or providing any services to, the organization beyond his or her duties as a committee member." Pathan (2009) finds that larger and more complex banks need more independent directors to bring innovations, diversity and independence into the decision-making process. J. Krishnan (2005) shows that audit committees with independent directors are extensively less likely to be associated with the incidence of internal control problems over financial reporting quality. Pomeroy and Thornton (2008) state that the independence of the audit committee has more of an impact in enhancing the audit quality through averting going concern reports and auditor resignations than it is in enhancing accruals quality and avoiding restatement. Abbott et al. (2004) confirm that an audit committee consisting of independent members, and that meets at least twice per year, decreases the possibility that the firm will be associated with misleading and fraudulent reporting. However, Dionne and Triki (2005) and Marsden and Prevost (2005) report evidence suggesting that the presence of outside, independent directors has no effect on a firm's risk management policy. An independent audit committee is unlikely to be effective unless the committee is also active (Haniffa \& Cooke, 2002). The second measure of audit committee structure is the percentage of independent members to the total number of audit committee. 
(3) Female audit committee members

Carter, Simkins, and Simpson (2003) show statistically a significant positive relationship between the percentage of female directors and non-bank firm value, as measured by Gul, Srinidhi, and $\mathrm{Ng}$ (2011), who find that stock prices of firms with gender-diverse boards are more informative. This suggests that a board's gender diversity may act as a supplementary mechanism for corporate governance. Srinidhi, Gul, and Tsui (2011) show a positive relationship between the presence of female audit committee members and earnings quality. This suggests that female directors are more effective monitors than their male counterparts. Our third measure of audit committee structure is the proportion of female directors on the audit committee.

\section{(4) Audit committee size}

Many previous studies have shown that the audit committee size has reduced operational efficiency. Board size, and its negative relationship with firm performance, is a common finding in the literature (Adams, Hermalin, \& Weisbach, 2010). Smaller boards are effective and value-additive because of their nimbleness, cohesiveness and lessened communication and coordination costs, as well as fewer 'free-riding' director problems (Lipton \& Lorsch, 1992). Directors in large boards may also face greater difficulties in expressing their opinions in the limited time available during board meetings (Lipton \& Lorsch, 1992). However, Aldamen and Duncan (2013) found that audit committee size had positively impact on firm performance during the Global Financial Crisis. Tai et al. (2018) find a significant and positive impact on a firm's decision of whether to hedge. Baxter and Cotter (2009) argue that large audit committees are more likely to have members with varied expertise for effective oversight, and suggest that large audit committees may have higher monitoring effectiveness. Our fourth measure of audit committee structure is the number of committee members.

\section{Measure external audit quality}

As stated before, we use external audit quality to check the external audit role for the relationship between audit committee structure and bank stability. A number of studies examine whether auditor branding, measured by auditor size (Big 6/5/4), is associated with earnings quality. For example, Becker, DeFond, Jiambalvo, and Subramanyam (1998) and Francis and Schipper (1999) argue that Big 6 auditors are better able to detect earnings management because of their superior knowledge, and act to curb earnings management to protect their reputation. Fan and Wong (2005) suggest that external auditors play a governance role in East Asia. Firms are more likely to hire name-brand auditors when their ownership structures indicate agency conflicts. In contrast with the scandals that challenge the credibility of well known audit firms, many academic studies tend to demonstrate that the name-brand audit networks (today's Big 4) are statistically more conservative in their opinions, and are more likely to constrain opportunistic accounting practices and enhance the oversight roles of the audit committee. We use well known audit firms (Big 4) to measure external audit quality.

\section{Other control variables}

We use the logarithm of total assets to control for size, as larger banks are frequently subject to "too big to fail" policies. Hutchinson and $\mathrm{Gul}(2004)$ also find that firm size is positively related to financial leverage and firm risk. To consider the fact that better diversified banks are assumed to be less risky, we control for diversification, measured by a diversification index (Demirgüç-Kunt \& Huizinga, 2010; Laeven \& Levine, 2009). We use the ratio of loan loss provisions to total assets as a measure of asset quality. To control ownership structure (as a proxy of agency conflict), we use proportion of state of equity and foreign equity to total equity. In addition, we use the net interest margin (NIM) to understand the impact of banking spread with regards to their "traditional activities" on bank stability. Higher values are expected to improve stability. However, Dwumfour (2017) has found that the spread-stability relationship is an inverted U-shaped relationship. Where banks are charging interest that is too high, borrowers are likely to venture into too-risky projects in order to pay their loans and interests. In this regard, it is likely to increase default rates and hence non-performing loans, leading to an unstable industry. 
Models

First, we examine the effect of audit committee structure on risk-taking based on the following model:

$\mathrm{STAB}=\alpha_{0}+\alpha_{1} \mathrm{FAC}+\alpha_{2} \mathrm{ACS}+\alpha_{3} \mathrm{ACD}+\alpha_{4} \mathrm{FNE}+\alpha_{5} \mathrm{SIZE}+\alpha_{6} \mathrm{NIM}+\alpha_{7} \mathrm{FOW}+\alpha_{8} \mathrm{SO}+\alpha_{9} \mathrm{DIV}+\alpha_{10} \mathrm{ASQ}+\varepsilon$ (1)

Where:

STAB = bank stability, measured by Z-score and non-performing loan ratio (NPLS)

$\mathrm{FAC}=$ female audit committee member, measured by the proportion of female members on the audit committee

ACS $=$ audit committee size, measured by the number of audit committee members

$\mathrm{ACD}=$ audit committee independence, measured by the proportion of independent directors on the audit committee

$\mathrm{FNE}=$ accounting or financial expertise, measured by the proportion of members with accounting or financial expertise on the audit committee

SIZE $=$ bank size, measured by the natural logarithm of total assets

NIM = net interest margin, measured by the accounting value of the bank's net interest revenue as a share of its average interest-bearing (total earning) assets

FOW $=$ foreign ownership, measured by the proportion of foreign share to total share

$\mathrm{SO}=$ state ownership, measured by the proportion of state share to total share

DIV= diversification index, measured by:

(1 - (|Net interest income - Other operating income $) \mid /$ Total operating income $)$

$\mathrm{ASQ}=$ Asset quality, measured by ratio of loan loss provisions to total assets

Second, we examine the effect of external audit quality on the association between audit committee structure and bank stability by estimating the following model:

$\mathrm{STAB}=\beta_{0}+\beta_{1} \mathrm{FAC} * \mathrm{EXA}+\beta_{2} \mathrm{ACS} * \mathrm{EXA}+\beta_{3} \mathrm{ACD} * \mathrm{EXA}+\beta_{4} \mathrm{FNE} * \mathrm{EXA}+\beta_{5} \mathrm{SIZE}+\beta_{6} \mathrm{NIM}+\beta_{7} \mathrm{FOW}+$ $\beta_{8} \mathrm{SO}+\beta_{9} \mathrm{DIV}+\beta_{10} \mathrm{ASQ}+\varepsilon$

Where:

EXA = external audit quality, is equal 1 if bank use Big 4 for audit service, and 0 otherwise.

In this paper, we use the fixed effects model (FEM) and two-stage least squares (2SLS) regression analysis, as well as the system GMM, as robustness checks. The system GMM estimator, which is a product of the work done by Blundell and Bond (1998), helps us to address the possible endogeneity issues associated with the various determinants of financial stability. We test the instrument validity by using Hansen's J statistic of overidentifying restrictions (Hansen, 2000). The Hansen's J statistic is used in place of the Sargan test of overidentifying restrictions because of its consistency in the presence of autocorrelation and heteroscedasticity (Neanidis \& Varvarigos, 2009; Roodman, 2007). Then, we use the Arellano and Bond (1991) AR (1) and AR (2) tests for first- and second-order serial autocorrelation. For system GMM, we only check for the absence of second-order serial autocorrelation.

Moreover, we examine heterogeneous responses to audit committee structure using quantile regressions. The results obtained with quantile regressions highlight another previously neglected phenomenon. Bank boards need to consider that the effect of audit committee on stability is conditional upon the stability of the banks operating. An additional advantage of using quantile regression is that it can mitigate some statistical problems, such as sensitivity to outliers and non-Gaussian error distribution (Barnes \& Hughes, 2002). This study estimates the coefficients at five quantiles, namely the 10th, 25th, 50th, 75th, and 90th quantiles, using the same list of governance and control variables. It is expected that different effects of the explanatory variables at the different quantiles are reflected in the size, sign and significance of the estimated coefficients of the different variables. 


\section{Empirical analysis}

This section presents the results for the empirical testing of the hypotheses. There are three parts in this section. Section 4.1 presents an overview of descriptive statistics of the research data. Section 4.2 presents empirical result of testing $\mathrm{H} 1$ and $\mathrm{H} 2$, which relate to the relationship between audit committee structure and bank stability. Section 4.3 presents the empirical results of testing $\mathrm{H} 3$.

\section{Descriptive statistics}

Table 1. Descriptive statistics

\begin{tabular}{llllllll}
\hline Variable & Obs & Mean & Std. Dev. & Min & Q25 & Q75 & Max \\
\hline Z-score & 404 & 13.35 & 8.63 & 0.83 & 8.56 & 15.12 & 74.11 \\
NPLS & 404 & 0.02 & 0.02 & 0.00 & 0.01 & 0.03 & 0.17 \\
FAC & 404 & 0.46 & 0.28 & 0.00 & 0.33 & 0.67 & 1.00 \\
ACS & 404 & 3.28 & 0.95 & 0.00 & 3.00 & 4.00 & 7.00 \\
ACD & 404 & 0.08 & 0.16 & 0.00 & 0.00 & 0.00 & 1.00 \\
FNE & 404 & 0.49 & 0.28 & 0.00 & 0.33 & 0.67 & 1.00 \\
SIZE & 404 & 9.51 & 0.58 & 7.72 & 9.07 & 9.92 & 10.75 \\
NIM & 404 & 0.03 & 0.01 & -0.02 & 0.02 & 0.04 & 0.10 \\
FOW & 404 & 0.09 & 0.14 & 0.00 & 0.00 & 0.20 & 0.96 \\
SO & 404 & 0.19 & 0.32 & 0.00 & 0.00 & 0.24 & 1.00 \\
DIV & 404 & 0.17 & 1.64 & -26.21 & 0.20 & 0.25 & 1.00 \\
ASQ & 404 & 0.01 & 0.01 & 0.00 & 0.00 & 0.00 & 0.22 \\
\hline
\end{tabular}

Note: All variables are as defined earlier.

The descriptive statistics of the major variables are described in Table 1. The mean of the Z-score is 13.35; the minimum value is 0.83 ; and the maximum value is 74.11 , showing that the stability differs greatly from bank to bank in Vietnam. The mean of the NPL ratio is $2 \%$ and ranges from $0 \%$ to $17 \%$. The audit committee structure of banks is also different. The proportion of female members and experts in financial accounting is $46 \%$ and $49 \%$, respectively. However, there is a significant difference between $0 \%$ and $100 \%$. The mean of audit committee size reaches 3.28 , while the minimum value is 0 and the highest is 7 members. The audit committee size of Vietnamese commercial banks is much smaller than that of developed countries, namely, 12 members on average (Zhang, Lin, Liu, \& SUN, 2014). In particular, the rate of independent members in Vietnamese commercial banks is quite low - only $8 \%$ on average - and the fluctuation is also very high (from 0\%-100\%). Meanwhile, the proportion of independent members according to Zhang et al. (2014) is $75.3 \%$ 
Table 2. Correlation matrix of main regression variables

\begin{tabular}{|c|c|c|c|c|c|c|c|c|c|c|c|c|}
\hline & Z-score & NPLS & FAC & ACS & ACD & FNE & SIZE & NIM & FOW & SO & DIV & ASQ \\
\hline NPLS & $(0.129)^{* * *}$ & 1.000 & & & & & & & & & & \\
\hline FAC & $(0.099) * *$ & $(0.015)$ & 1.000 & & & & & & & & & \\
\hline ACS & $(0.278)^{* * *}$ & $0.276^{* * *}$ & $(0.090)^{*}$ & 1.000 & & & & & & & & \\
\hline $\mathrm{ACD}$ & $0.153 * * *$ & 0.002 & $(0.156)^{* * *}$ & 0.030 & 1.000 & & & & & & & \\
\hline FNE & 0.066 & $(0.003)$ & 0.047 & 0.025 & 0.069 & 1.000 & & & & & & \\
\hline SIZE & $(0.597)^{* * *}$ & $0.159 * * *$ & $0.131 * * *$ & $0.211 * * *$ & $(0.043)$ & $(0.064)$ & 1.000 & & & & & \\
\hline NIM & $0.347 * * *$ & $(0.015)$ & 0.049 & $(0.208)^{* * *}$ & $0.114 * * *$ & 0.009 & $(0.110)^{* * *}$ & 1.000 & & & & \\
\hline FOW & $(0.076)$ & $(0.033)$ & $(0.132)^{* * *}$ & $0.133 * * *$ & $0.332 * * *$ & $0.096^{* *}$ & 0.074 & 0.070 & 1.000 & & & \\
\hline $\mathrm{SO}$ & $(0.275)^{* * *}$ & 0.020 & $(0.081)^{*}$ & $(0.063)$ & $(0.034)$ & $(0.394)^{* * *}$ & $0.425 * * *$ & 0.012 & $(0.148)^{* * *}$ & 1.000 & & \\
\hline DIV & 0.031 & 0.066 & $0.093^{*}$ & $(0.011)$ & 0.060 & $(0.061)$ & 0.019 & $0.091 * *$ & 0.015 & 0.076 & 1.000 & \\
\hline ASQ & 0.079 & $(0.022)$ & $(0.066)$ & $(0.033)$ & $(0.065)$ & 0.001 & $(0.132)^{* * *}$ & $0.165^{* * *}$ & $(0.081)^{*}$ & 0.071 & 0.042 & 1.000 \\
\hline
\end{tabular}

Note: $* \mathrm{p}<0.1 ; * * \mathrm{p}<0.05 ; * * * \mathrm{p}<0.01$ (two-tailed tests). 
Table 2 presents the correlation coefficients for the independent variables used in the regression models to examine whether there are highly correlated variables. We find that the largest absolute value of correlation coefficients is 0.597 for a negative correlation between bank size (Size) and bank stability (Z-score). This indicates that their inclusion will not present any problem of multicollinearity, since they are less than 0.70 (Kennedy, 2008). Table 2 also shows that more stable banks (as measured by a higher Z-score or NPL ratio) have a lower proportion of female member on audit committees and in terms of audit committee size, but have a higher proportion of dependent audit committee members and financial and accounting experts.

\section{Audit committee structure and bank stability}

We present the results of analyzing the relationship between audit committee structure and bank stability in Table 3 . Columns (1) and (2) present the results for the model with the dependent variables of Z-score and NPLS, respectively, using FEM. Similarly, columns (3) and (4) use 2SLS, and columns (5) and (6) use GMM. We find that the coefficient on ACS is negative with Z-score and positive with NPLS. The results show that the audit committee size correlates negatively with the bank stability. This result is different to that of Tai et al. (2018) and does not support the work of Baxter and Cotter (2009). Tai et al. (2018) identified a negative relation between audit committee size and firm risk, but their study only focused on large firms in developed markets. Vietnam is currently a developing country. Vietnamese banks are much smaller than developed countries. Therefore, the large and complex governance may cause it to function ineffectively. Our result is consistent with the non-bank evidence on the negative association between board size and firm performance (Bhagat \& Black, 2002; Hermalin \& Weisbach, 1991). It also supports the work of Aldamen and Duncan (2013). A larger audit committee size can also lead to inefficient governance, thus reducinf risk management efficiency and bank stability. 
Table 3. The effect of audit committee structure on bank stability

\begin{tabular}{|c|c|c|c|c|c|c|}
\hline & $\mathrm{FE}$ & & 2SLS & & S-GMM & \\
\hline & (1) & (2) & (3) & (4) & (5) & (6) \\
\hline Variables & Z-score & NPLS & Z-score & NPLS & Z-score & NPLS \\
\hline FAC & 0.930 & 0.003 & $-3.141 * *$ & -0.001 & -7.509 & -0.140 \\
\hline ASC & $-0.676 *$ & $0.006 * * *$ & $-1.486^{* * *}$ & $0.006 * * *$ & $-4.159 * * *$ & $0.007 * * *$ \\
\hline $\mathrm{ACD}$ & -0.210 & $0.026 * * *$ & $7.382 * *$ & 0.001 & 5.087 & $0.023 * * *$ \\
\hline FNE & -2.202 & -0.004 & -0.557 & 0.0005 & $23.176 * *$ & $-0.030 * *$ \\
\hline SIZE & $-7.268 * * *$ & 0.002 & $-4.455 * * *$ & 0.001 & $-7.409 * * *$ & 0.007 \\
\hline NIM & $153.875^{* * *}$ & 0.084 & $162.317 * * *$ & 0.071 & $639.828 * * *$ & 0.007 \\
\hline FOW & $-3.234 *$ & $-0.016 * *$ & $-8.775^{* * *}$ & $-0.012 *$ & 5.688 & 0.001 \\
\hline $\mathrm{SO}$ & $-3.049 *$ & $-0.013 * *$ & $-5.232 * * *$ & 0.0007 & -440.623 & -0.050 \\
\hline DIV & 0.264 & $0.001 * *$ & 0.141 & $0.0008 * * *$ & 2.117 & -0.014 \\
\hline ASQ & -12.133 & -0.009 & -6.243 & -0.045 & -8.368 & -0.006 \\
\hline $\mathrm{R} 2$ & 0.27 & 0.10 & 0.45 & 0.09 & & \\
\hline LM test & & & $60.905 * * *$ & $79.586 * * *$ & & \\
\hline Hansen test & & & 0.870 & 0.74 & 0.78 & 0.519 \\
\hline Endogeneity test & & & $5.957 * *$ & $2.702 *$ & & \\
\hline $\mathrm{AR}(2)$ & & & & & 0.246 & 0.104 \\
\hline
\end{tabular}

Note: All variables are as defined earlier

Note: $* \mathrm{p}<0.1 ; * * \mathrm{p}<0.05 ; * * * \mathrm{p}<0.01$ (two-tailed tests).

Unlike the research conducted by Sun and Liu (2014), which focuses on large financial firms in the Standard \& Poor's (S\&P) 1500, our results presented in Table 3 show that the proportion of financial and accounting experts in the audit committee is positively correlated with bank stability when measured by both the Z-score and NPLS. However, the coefficients estimated by the FEM and 2SLS methods are statistically insignificant. Our results implicate that financial and accounting experts are more important in emerging and developing markets than in a developed market. These results are also consistent with the work of Tai et al. (2018). Because financial experts are knowledgeable about bank risk, they can effectively oversee risk management issues. These results support H1, which posited that there is relation between the audit committee structure and bank stability, although we find no evidence about a relationship between the proportion of independent and female members in the audit committee.

We also find certain results in Table 3 to be consistent with past studies. First, bank size negatively affects bank stability (measured by Z-score). The larger banks in Vietnam are frequently subject to "too-big-to-fail" policies, and they tend to take more risks. This finding is consistent with previous studies (Hutchinson \& Gul, 2004; Sun \& Liu, 2014; Tai et al., 2018). Second, the net interest margin (NIM) is positively associated with bank stability. The NIM of Vietnamese banks is not too high in our research period. This result is consistent with the work of Dwumfour (2017), which showed that banking spread (NIM) is the main determinant of stability. 
In addition, we use quantile regression to allow for heterogeneous responses to competition in Table 4 by conditioning on bank stability. When Z-score is used as a dependent variable, we find that ACD is significantly and positively associated with Z-score in the range from quantile 0.75 to 0.9 , with the effect being larger in the higher quantiles, but not significant in low quantiles. This implies that the role of independent members in retaining bank stability is more important in banks with high levels of stability. Using the NPLS as our dependent variable, we find that coefficients of ACS and NPLS remain negative and significant across the quantiles from 0.25 to 0.9. The coefficients also increase from quantile 0.25 to 0.9 . This means that the higher the stability, the higher the (negative) impact of audit committee size on the bank stability. In general, these findings show that the relationship between audit committee structure and bank stability is different across quantiles, which is again something that cannot be captured by applying the classical linear regression. These result consistent with Schaeck and Cihak (2012), who demonstrated that the important role of governance is different and dependent on the level of bank stability. Our results support $\mathrm{H} 2$. The quantile regression results highlight the fact that bank boards should consider that any audit committee structure may affect stability differently in the relevant bank depending upon the bank's stability. 
Table 4. The effect of audit committee structure on bank stability by quantile regression

\begin{tabular}{|c|c|c|c|c|c|c|c|c|}
\hline Model setup & Quantile re & ion & & & & & & \\
\hline Independent Variables & Z-score & & & & NPLS & & & \\
\hline Dependent variables & Q25 & Q50 & Q75 & Q90 & Q25 & Q50 & Q75 & Q90 \\
\hline FAC & 0.0333 & -0.9803 & 1.5058 & -0.8161 & 0.0003 & 0.0023 & -0.0045 & -0.0080 \\
\hline ASC & 0.0710 & -0.1230 & -0.6058 & -1.0651 & $0.0037 * * *$ & $0.0048 * * *$ & $0.0054 * * *$ & $0.0060 * * *$ \\
\hline $\mathrm{ACD}$ & 1.6683 & 1.8321 & $7.0087 * *$ & $15.9408 * * *$ & -0.0028 & -0.0068 & -0.0088 & 0.0145 \\
\hline FNE & 1.2513 & 0.9638 & -0.1198 & -1.6262 & -0.0007 & -0.0024 & -0.0049 & 0.0051 \\
\hline SIZE & $-3.5831 * * *$ & $-5.5947 * * *$ & -8.3196 & $-10.583^{* * *}$ & $-0.0045 * * *$ & -0.0019 & 0.0045 & $0.0193 * * *$ \\
\hline NIM & $84.2211 * * *$ & $94.5116^{* * *}$ & $53.1484 *$ & 71.8833 & -0.0368 & 0.0653 & 0.0727 & -0.0076 \\
\hline FOW & -1.1845 & -1.4242 & $-6.7373 *$ & -9.2131 & 0.0054 & -0.0019 & -0.01 & -0.0308 \\
\hline SO & $-1.1170^{* * *}$ & -0.7556 & -1.2641 & -2.9110 & 0.0054 & 0.0012 & -0.0004 & -0.0132 \\
\hline DIV & 0.0965 & 0.2092 & -0.1437 & 0.0775 & 0.0003 & 0.0004 & 0.0007 & -0.0013 \\
\hline ASQ & -7.5275 & $38.3066^{*}$ & $136.6493 * * *$ & 291.6309 & 0.0057 & -0.0206 & -0.0301 & 0.0194 \\
\hline Obs & 404 & 404 & 404 & 404 & 404 & 404 & 404 & 404 \\
\hline
\end{tabular}

Note: All variables are as defined earlier.

Note: ${ }^{*} \mathrm{p}<0.1 ; * * \mathrm{p}<0.05 ; * * * \mathrm{p}<0.01$ (two-tailed tests). 


\section{Role of external audit}

Table 5 reports the results on how external audit influences the relationship between audit committee structure and bank stability. In the first 2 columns of Table 5, we present the results for Z-score, two next columns present the results for NPLS. First, the results show that the audit committee size (ASC) has a negative correlation and is statistically significant with the bank stability. Specifically, the regression coefficients have a negative impact on the ASC variable but have a positive impact on the NPLS variable. However, the estimated coefficient of the ASC*EXA variable is positively and statistically correlated with Z-score and is negatively correlated with NPLS. The results supports to $\mathrm{H} 3$ hypothesis. This means that the external audit is likely to limit the inverse relationship between audit committee size and bank stability.

Table 5. The effect of audit committee structure on bank stability with role of external audit

\begin{tabular}{|c|c|c|c|c|}
\hline & 2SLS & & S-GMM & \\
\hline Variables & Z-score & NPLS & Z-score & NPLS \\
\hline FAC & -2.7970 & $-0.0161 * * *$ & 18.3495 & $-0.0732 *$ \\
\hline ASC & $-2.1202 * * *$ & $0.0069 * * *$ & $-8.6382 *$ & $0.0209 * *$ \\
\hline $\mathrm{ACD}$ & 1.5220 & 0.0023 & -49.4507 & 0.0489 \\
\hline FNE & $12.3514 * * *$ & 0.0052 & 44.08577 & -0.0151 \\
\hline FAC*EXA & 1.8990 & $0.0204 * * *$ & -27.1122 & $0.0834 * *$ \\
\hline ASC*EXA & $1.3031 * *$ & $-0.0036 *$ & 7.3451* & $-0.0163 *$ \\
\hline ACD*EXA & 7.0140 & 0.0073 & 48.6864 & -0.0343 \\
\hline FNE*EXA & $-14.6750 * * *$ & -0.0092 & -27.9647 & -0.0314 \\
\hline SIZE & $-5.2773 * * *$ & $0.0094 * * *$ & -6.6331 & 0.0081 \\
\hline NIM & $157.0277 * * *$ & $0.1147^{*}$ & $522.5397 * *$ & -0.0745 \\
\hline FOW & $-8.2333 * * *$ & $-0.0156 * *$ & -2.2209 & -0.0021 \\
\hline SO & $-3.8485 * * *$ & -0.0046 & 1.5518 & -0.0024 \\
\hline DIV & 0.1201 & $0.0006 * *$ & 4.5101 & -0.0021 \\
\hline ASQ & -31.5000 & -0.0266 & -522.6164 & -0.2548 \\
\hline R2 & 0.5 & 0.14 & & \\
\hline LM test & $58.271 * * *$ & $102.119 * * *$ & & \\
\hline Hansen test & 0.44 & 0.11 & 0.78 & 0.56 \\
\hline Endogeneity test & $3.095^{*}$ & $3.870^{* *}$ & & \\
\hline $\mathrm{AR}(2)$ & & & 0.174 & 0.31 \\
\hline
\end{tabular}

Note: All variables are as defined earlier.

Note: ${ }^{*} \mathrm{p}<0.1 ; * * \mathrm{p}<0.05 ; * * * \mathrm{p}<0.01$ (two-tailed tests). 
Our research results can be interpreted as showing that the risk management activity of audit committees in Big 4-audited firms tends to be greater than in non-Big 4-audited firms (Menon \& Williams, 1994). Reputable auditing companies provide better audit services than other auditing companies. The audit quality will put pressure on the audit committee to perform more efficiently. In addition, external audit quality will interact well with the individual bank's audit committee to improve the audit committee performance. These result are also consistent with the work of Francis and Schipper (1999) and Hohenfels and Quick (2018). This finding is very important for the Vietnamese banking system, where corporate governance is still not stable. These banks should retain a high quality external audit service.

\section{Conclusion}

A number of studies have sought to explain bank stability, although they are mostly based in developed markets. Only a limited number of studies focus on the relationship between bank governance and bank stability. This paper adds to the existing empirical literature by providing unique evidence from an emerging economy, which has as yet received little focus. This is the first study to identify the relationship of audit committee structure and bank stability in Vietnam (a developing country). We also identified the important role played by external audit quality in relation to audit committee structure and bank stability. External audit quality may increase the efficiency of audit committee risk oversight. Lastly, our results demonstrate the different effect of audit committee structure on bank stability. These empirical results indicate that the audit committee structure is correlated with bank stability depending on external audit quality and the level of bank stability. This may give interesting insights into how governance structures for Vietnamese banks can retain stability. Based on our results, banks that have large audit committees should consider a high quality external audit service and should increase the number of financial and accounting experts in their audit committees in order to ensure bank stability.

\section{References}

Abbott, L. J., Park, Y., \& Parker, S. (2000). The effects of audit committee activity and independence on corporate fraud. Managerial Finance, 26(11), 55-68.

Abbott, L. J., Parker, S., \& Peters, G. F. (2004). Audit committee characteristics and restatements. Auditing: A Journal of Practice \& Theory, 23(1), 69-87.

Adams, R. B., Hermalin, B. E., \& Weisbach, M. S. (2010). The role of boards of directors in corporate governance: A conceptual framework and survey. Journal of economic literature, 48(1), 58-107.

Aldamen, H., \& Duncan, K. (2013). Pricing of innate and discretionary accruals in Australian debt. Accounting \& Finance, 53(1), 31-53.

Arellano, M., \& Bond, S. (1991). Some tests of specification for panel data: Monte Carlo evidence and an application to employment equations. The review of economic studies, 58(2), 277-297.

Barnes, M. L., \& Hughes, A. T. W. (2002). A quantile regression analysis of the cross section of stock market returns.

Baxter, P., \& Cotter, J. (2009). Audit committees and earnings quality. Accounting \& Finance, 49(2), 267-290.

Becker, C. L., DeFond, M. L., Jiambalvo, J., \& Subramanyam, K. (1998). The effect of audit quality on earnings management. Contemporary Accounting Research, 15(1), 1-24.

Bédard, J., Chtourou, S. M., \& Courteau, L. (2004). The effect of audit committee expertise, independence, and activity on aggressive earnings management. Auditing: A Journal of Practice \& Theory, 23(2), 13-35.

Benston, G. J. (1965a). Branch banking and economies of scale. The Journal of Finance, 20(2), 312-331.

Benston, G. J. (1965b). Economies of Scale and Marginal Cost in Banking Operations, National Banking Review.

Berger, A. N., Imbierowicz, B., \& Rauch, C. (2016). The roles of corporate governance in bank failures during the recent financial crisis. Journal of Money, Credit and Banking, 48(4), 729-770.

Bhagat, S., \& Black, B. (2002). The Non-Correlation Between Board Independence.

Blundell, R., \& Bond, S. (1998). Initial conditions and moment restrictions in dynamic panel data models. Journal of econometrics, 87(1), 115-143.

Caprio, G., Laeven, L., \& Levine, R. (2007). Governance and bank valuation. Journal of Financial Intermediation, 16(4), 584617.

Carter, D. A., Simkins, B. J., \& Simpson, W. G. (2003). Corporate governance, board diversity, and firm value. Financial review, 38(1), 33-53.

Cornett, M. M., Marcus, A. J., Saunders, A., \& Tehranian, H. (2006). Earnings management, corporate governance, and true financial performance. Available at SSRN 886142.

Demirgüç-Kunt, A., \& Huizinga, H. (2010). Bank activity and funding strategies: The impact on risk and returns. Journal of Financial Economics, 98(3), 626-650. 
Demirgüç-Kunt, A., \& Maksimovic, V. (1998). Law, finance, and firm growth. The Journal of Finance, 53(6), $2107-2137$.

Dewatripont, M., \& Tirole, J. (1994). The prudential regulation of banks. Retrieved from

Dhaliwal, D., Naiker, V., \& Navissi, F. (2010). The association between accruals quality and the characteristics of accounting experts and mix of expertise on audit committees. Contemporary Accounting Research, 27(3), 787-827.

Dionne, G., \& Triki, T. (2005). Risk management and corporate governance: The importance of independence and financial knowledge for the board and the audit committee. HEC Montreal Working Paper No. 05-03

Dwumfour, R. A. (2017). Explaining banking stability in Sub-Saharan Africa. Research in International Business and Finance, 41, 260-279.

Fama, E. F., \& Jensen, M. C. (1983). Separation of ownership and control. The journal of law and Economics, 26(2), $301-325$.

Fan, J. P., \& Wong, T. J. (2005). Do external auditors perform a corporate governance role in emerging markets? Evidence from East Asia. Journal of accounting Research, 43(1), 35-72.

Francis, J., \& Schipper, K. (1999). Have financial statements lost their relevance? Journal of accounting Research, 37(2), 319352.

Gillan, S. L. (2006). Recent developments in corporate governance: An overview: Elsevier.

Gul, F. A., Srinidhi, B., \& Ng, A. C. (2011). Does board gender diversity improve the informativeness of stock prices? Journal of Accounting and Economics, 51(3), 314-338.

Haniffa, R. M., \& Cooke, T. E. (2002). Culture, corporate governance and disclosure in Malaysian corporations. Abacus, 38(3), 317-349.

Hansen, B. E. (2000). Testing for structural change in conditional models. Journal of Econometrics, 97(1), 93-115.

Hermalin, B. E., \& Weisbach, M. S. (1991). The effects of board composition and direct incentives on firm performance. Financial management, 101-112.

Hohenfels, D., \& Quick, R. (2018). Non-audit services and audit quality: evidence from Germany. Review of Managerial Science, $1-49$.

Houston, J. F., Lin, C., Lin, P., \& Ma, Y. (2010). Creditor rights, information sharing, and bank risk taking. Journal of Financial Economics, 96(3), 485-512.

Hutchinson, M., \& Gul, F. A. (2004). Investment opportunity set, corporate governance practices and firm performance. Journal of Corporate Finance, 10(4), 595-614.

Iskandar, T. M., Jamil, A., Yatim, P., \& Sanusi, Z. M. (2018). The role of internal audit and audit committee in the implementation of enterprise risk management. International Journal of Business and Globalisation, 21(2), 239-260.

Jimenez, G., Salas, V., \& Saurina, J. (2006). Determinants of collateral. Journal of Financial Economics, 81(2), $255-281$.

John, K., \& Senbet, L. W. (1998). Corporate governance and board effectiveness. Journal of banking \& Finance, $22(4), 371$-403.

Kennedy, P. (2008). A guide to econometrics. 2008. Malden, MA: Blackwell.

Krishnan, G. V., \& Visvanathan, G. (2008). Does the SOX definition of an accounting expert matter? The association between audit committee directors' accounting expertise and accounting conservatism. Contemporary Accounting Research, 25(3), 827858 .

Krishnan, J. (2005). Audit committee quality and internal control: An empirical analysis. The accounting review, 80(2), 649675.

Laeven, L., \& Levine, R. (2009). Bank governance, regulation and risk taking. Journal of Financial Economics, 93(2), $259-275$.

Levine, R., \& Barth, J. (2001). Bank regulation and supervision: what works best? : The World Bank.

Lin, J. W., \& Hwang, M. I. (2010). Audit quality, corporate governance, and earnings management: A meta-analysis. International Journal of Auditing, 14(1), 57-77.

Lipton, M., \& Lorsch, J. W. (1992). A modest proposal for improved corporate governance. The business lawyer, 59-77.

Marsden, A., \& Prevost, A. K. (2005). Derivatives use, corporate governance, and legislative change: an empirical analysis of New Zealand listed companies. Journal of Business Finance \& Accounting, 32(1-2), 255-295.

Menon, K., \& Williams, J. D. (1994). The use of audit committees for monitoring. Journal of accounting and public policy, 13(2), 121-139.

Minton, B. A., Taillard, J., \& Williamson, R. (2011). Do independence and financial expertise of the board matter for risk taking and performance? Available at SSRN 1787126.

Neanidis, K. C., \& Varvarigos, D. (2009). The allocation of volatile aid and economic growth: Theory and evidence. European Journal of Political Economy, 25(4), 447-462.

Pathan, S. (2009). Strong boards, CEO power and bank risk-taking. Journal of Banking \& Finance, 33(7), $1340-1350$.

Pérez-Cornejo, C., de Quevedo-Puente, E., \& Delgado-García, J. B. (2019). How to manage corporate reputation? The effect of enterprise risk management systems and audit committees on corporate reputation. European Management Journal.

Pincus, K., Rusbarsky, M., \& Wong, J. (1989). Voluntary formation of corporate audit committees among NASDAQ firms. Journal of accounting and public policy, 8(4), 239-265.

Pomeroy, B., \& Thornton, D. B. (2008). Meta-analysis and the accounting literature: The case of audit committee independence and financial reporting quality. European Accounting Review, 17(2), 305-330.

Roodman, D. (2007). The anarchy of numbers: aid, development, and cross-country empirics. The World Bank Economic Review, 21(2), 255-277.

Schaeck, K., \& Cihak, M. (2012). Banking competition and capital ratios. European Financial Management, 18(5), 836-866. 
Schaeck, K., Cihak, M., Maechler, A., \& Stolz, S. (2011). Who disciplines bank managers? Review of Finance, 16(1), 197-243. Shleifer, A., \& Vishny, R. W. (1989). Management entrenchment: The case of manager-specific investments. Journal of Financial Economics, 25(1), 123-139.

Shleifer, A., \& Vishny, R. W. (1997). A survey of corporate governance. The Journal of Finance, 52(2), 737-783.

Srinidhi, B., Gul, F. A., \& Tsui, J. (2011). Female directors and earnings quality. Contemporary Accounting Research, 28(5), 1610-1644.

Sun, J., \& Liu, G. (2014). Audit committees' oversight of bank risk-taking. Journal of Banking \& Finance, 40, 376-387.

Tai, V. W., Lai, Y.-H., \& Yang, T.-H. (2018). The role of the board and the audit committee in corporate risk management. The North American Journal of Economics and Finance.

Wild, J. J. (1996). The audit committee and earnings quality. Journal of Accounting, Auditing \& Finance, 11(2), 247-276.

Xie, B., Davidson III, W. N., \& DaDalt, P. J. (2003). Earnings management and corporate governance: the role of the board and the audit committee. Journal of Corporate Finance, 9(3), 295-316.

Zhang, B., Lin, Y., Liu, W., \& SUN, J. (2014). Debate on urban development boundary: the perspective of spatial governance in China. Paper presented at the Urban Planning Forum. Creative Commons Attribution (CC BY SA) license (https://creativecommons.org/licenses/by-sa/4.0/) 